\title{
Carbohydrate derived energy and gross energy absorption in preterm infants fed human milk or formula
}

\author{
M DE CURTIS, J SENTERRE, J RIGO, AND G PUTET
}

Departments of Neonatology, University Hospital, Liège, Belgium, Seconda Facoltà di Medicina, Napoli, Italy, and University Hospital E Herriot, Lyon, France

SUMMARY Significant production of breath hydrogen has been shown in premature infants, suggesting limited intestinal capacity for digestion of carbohydrate. To evaluate net absorption of carbohydrate 24 three day balance studies were carried out in seven preterm infants fed pasteurised banked human milk and in 17 preterm infants fed a formula containing $75 \%$ lactose and $25 \%$ glucose polymers. Because carbohydrate reaching the colon may be converted to organic acids by bacterial flora, carbohydrate net absorption was determined by quantitating the faecal excretion of energy derived from carbohydrate. The carbohydrate derived energy content of milk and stools was calculated as the difference between the measured gross energy and the sum of energy related to nitrogen and fat. Faecal loss of carbohydrate derived energy was lower in the group fed formula $(1.9$ (SD 1.2) $\mathrm{kcal} / \mathrm{kg} /$ day) than in the group fed human milk $(4.0$ (SD $1 \cdot 8) \mathrm{kcal} / \mathrm{kg} /$ day). Net absorption of carbohydrate derived energy was $97 \cdot 0$ (SD 1.9)\% as opposed to 92.6 (SD 3.9$) \%$, respectively. Within each group there was no significant relation between carbohydrate energy absorption and fat, nitrogen, or gross energy absorption. Thus, although less complete with human milk than with formula, apparent absorption of energy derived from carbohydrate seemed quite satisfactory in these preterm infants.

Development of intestinal lactase activity occurs late in gestation. ${ }^{1}$ According to some studies, virtually all premature infants would be expected to have lactose malabsorption. ${ }^{23}$

Carbohydrate absorption in neonates has been estimated by various methods, but these methods often have limitations. Oral tolerance tests ${ }^{4}$ require a lot of blood samples and are often unreliable. Measurement of breath hydrogen ${ }^{2}{ }^{3}$ is a sensitive but non-quantitative method of evaluating carbohydrate malabsorption. Determination of lactose assimilation by using stable, isotopically labelled molecules $^{5}$ requires sophisticated and expensive equipment. Balance studies with measurements of faecal excretion of carbohydrate ${ }^{6-8}$ do not necessarily provide accurate information of intestinal digestibility as carbohydrate reaching the colon may be converted by bacterial enzymatic actions to lactic acid and short chain fatty acids.

In 1982 Kien et al developed a method for assessing carbohydrate absorption by measuring gross energy, nitrogen, and fat content of intake and stools. ${ }^{9}$ Using this method, we evaluated gross energy and carbohydrate derived energy absorption in preterm infants fed human milk or a preterm formula.

\section{Patients and methods}

Twenty four three day balance studies were carried out in 24 preterm boys (Table 1). All infants were

Table 1 Infant data according to feeding group. Values are mean (SD)

\begin{tabular}{lcc}
\hline & \multicolumn{2}{l}{ Feeding group } \\
\cline { 2 - 3 } & $\begin{array}{l}\text { Human } \\
\text { milk }\end{array}$ & $\begin{array}{c}\text { Preterm } \\
\text { formula }\end{array}$ \\
\hline $\begin{array}{l}\text { No of infants } \\
\text { At birth: }\end{array}$ & 7 & 17 \\
$\begin{array}{l}\text { Gestational age (wks) } \\
\text { Weight (g) }\end{array}$ & $31(1)$ & $30(2)$ \\
$\begin{array}{l}\text { At balance study: } \\
\text { Postnatal age (days) } \\
\text { Weight (g) }\end{array}$ & $1451(115)$ & $1326(240)$ \\
\hline
\end{tabular}


appropriate for gestational age. All were fed orally. At the time of the balance studies, all infants were passing normal stools and were growing at a steady rate. Informed parental consent was obtained.

The balance studies were carried out in seven infants fed pasteurised banked human milk and in 17 infants fed a preterm formula (Pregallia, Gallia, France) containing per $\mathrm{dl}$ : protein $1.9 \mathrm{~g}$ (whey:

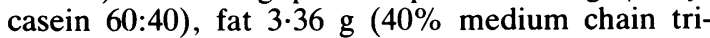
glycerides), and carbohydrate $9.6 \mathrm{~g}$ (75\% lactose and $25 \%$ maltodextrin). Separate collections of stools and urine were performed with a metabolic bed as previously described. ${ }^{10}$ Whenever defecation occurred the stool was immediately frozen. Total nitrogen was determined in both milk and faeces by the micro-kjeldahl technique and fat by a gravimetric method that gives complete recovery of long chain and medium chain triglycerides. ${ }^{11}$ Gross energy was determined on lyophilised aliquots of milk and stools using a ballistic bomb calorimeter (Gallenkamp, London, England) as reported elsewhere. ${ }^{12}$ The heat of combustion of various nutrients determined in our laboratory was protein $6.15 \mathrm{kcal} / \mathrm{g}$, long chain triglycerides $9.61 \mathrm{kcal} / \mathrm{g}$, and medium chain triglycerides $8.51 \mathrm{kcal} / \mathrm{g} .{ }^{12}$ The carbohydrate derived energy content of milk and stools was calculated as the difference between the measured gross energy and the sum of calculated gross energy related to nitrogen and fat content. The coefficients of net absorption of nitrogen, fat, carbohydrate derived energy, and gross energy were calcuated as:

\section{(intake-fecal excretion)/intake.}

The significance of the difference between two arithmetic means was evaluated by Student's $t$ test.

\section{Results}

Milk volume and fat intake were similar in both groups, but gross energy and nitrogen intakes were significantly higher in the preterm infants fed formula (Table 2). Carbohydrate derived energy intake averaged $54.4 \mathrm{kcal} / \mathrm{kg} /$ day in the group fed human milk and $63.7 \mathrm{kcal} / \mathrm{kg} /$ day in the group fed formula. In both groups this represented $46 \%$ of gross energy intake. The faecal excretions and coefficients of net absorption of gross energy, nitrogen, fat, and carbohydrate derived energy are shown in Table 3. Faecal excretions of gross energy, fat, and carbohydrate derived energy were roughly twice as high in the preterm infants fed pasteurised banked human milk as in those fed formula.

Gross energy absorption averaged $92.6 \%$ in the group fed formula as opposed to $85.5 \%$ in the group fed human milk. Net absorption of nitrogen, fat, and carbohydrate derived energy was also signifi-
Table 2 Intake data according to feeding group. Values are mean (SD)

\begin{tabular}{|c|c|c|}
\hline & \multicolumn{2}{|l|}{ Feeding group } \\
\hline & $\begin{array}{l}\text { Human } \\
\text { milk }\end{array}$ & $\begin{array}{l}\text { Preterm } \\
\text { formula }\end{array}$ \\
\hline Milk volume $(\mathrm{ml} / \mathrm{kg} / \mathrm{d})$ & $174(14)$ & $166(12)$ \\
\hline Gross energy ( $\mathrm{kcal} / \mathrm{kg} / \mathrm{d})$ & $119 \cdot 6(10 \cdot 2)$ & $136.9(7.4)^{*}$ \\
\hline $\begin{array}{l}\text { Total nitrogen: } \\
\text { (mg/kg/d) } \\
\text { (kcal/kg/d) }\end{array}$ & $\begin{array}{l}403(33) \\
15 \cdot 5(1 \cdot 3)\end{array}$ & $\begin{array}{l}510(27)^{*} \\
19 \cdot 6(1.0)^{*}\end{array}$ \\
\hline $\begin{array}{l}\text { Fat: } \\
\quad(g / k g / d) \\
(\mathrm{kcal} / \mathrm{kg} / \mathrm{d})\end{array}$ & $\begin{array}{l}5 \cdot 17(0 \cdot 70) \\
49 \cdot 7(6 \cdot 7)\end{array}$ & $\begin{array}{c}5 \cdot 58(0 \cdot 31) \\
53.6(3 \cdot 0)\end{array}$ \\
\hline $\begin{array}{l}\text { Carbohydrate derived energy } \\
(\mathrm{kcal} / \mathrm{kg} / \mathrm{d})\end{array}$ & $54 \cdot 4(6 \cdot 0)$ & $63.7(4.5)^{*}$ \\
\hline
\end{tabular}

${ }^{*} \mathrm{p}<0.05$ compared with the group fed human milk.

Table 3 Faecal excretion data according to feeding group. Values are mean (SD)

\begin{tabular}{|c|c|c|}
\hline & \multicolumn{2}{|c|}{ Feeding group } \\
\hline & $\begin{array}{l}\text { Human } \\
\text { milk }\end{array}$ & $\begin{array}{l}\text { Preterm } \\
\text { formula }\end{array}$ \\
\hline \multicolumn{3}{|l|}{ Gross energy: } \\
\hline$(\mathrm{kcal} / \mathrm{kg} / \mathrm{d})$ & $17 \cdot 3(5 \cdot 6)$ & $10 \cdot 1(3.3)^{*}$ \\
\hline (\% of absorption) & $85.5(4.9)$ & $92.6(2.4)^{*}$ \\
\hline \multicolumn{3}{|l|}{ Nitrogen: } \\
\hline$(\mathrm{mg} / \mathrm{kg} / \mathrm{d})$ & $64(20)$ & $50(16)$ \\
\hline$(\mathrm{kca} / \mathrm{kg} / \mathrm{d})$ & $2 \cdot 5(1 \cdot 0)$ & $1.9(1.0)$ \\
\hline (\% of absorption) & $84 \cdot 1(4 \cdot 5)$ & $90.2(2.9)^{*}$ \\
\hline \multicolumn{3}{|l|}{ Fat: } \\
\hline$(g / k g / d)$ & $1 \cdot 12(0 \cdot 50)$ & $0.65(0.27)^{*}$ \\
\hline$(\mathrm{kcal} / \mathrm{kg} / \mathrm{d})$ & $10 \cdot 8(4 \cdot 8)$ & $6.2(2 \cdot 6)^{*}$ \\
\hline (\% of absorption) & $78 \cdot 3(10 \cdot 0)$ & $88.4(4.9)^{*}$ \\
\hline \multicolumn{3}{|c|}{ Carbohydrate derived energy: } \\
\hline$(\mathrm{kcal} / \mathrm{kg} / \mathrm{d})$ & $4.0(1.8)$ & $1.9(1.2)^{*}$ \\
\hline (\% of absorption) & $92.6(3.9)$ & $97.0(1.9)^{*}$ \\
\hline
\end{tabular}

" $p<0.05$ compared with the group fed human milk.

cantly higher in the group fed formula than in the group fed human milk, these being $90 \cdot 2,88 \cdot 4$, and $97.0 \%$ as opposed to $84.1,78 \cdot 3$, and $92.6 \%$, respectively. Within each group, there was no significant relation between carbohydrate derived energy absorption and nitrogen absorption, fat absorption, gestational age, or postnatal age.

\section{Discussion}

The aim of this study was to quantitate net absorption of gross energy and carbohydrate derived energy in preterm infants fed human milk or a preterm formula.

In the group fed banked human milk the mean (SD) coefficient of gross energy absorption (86 (5)\%) was similar to that reported $(87(5) \%)$ by Whyte $e t$ al in very low birthweight infants fed their own mother's milk ${ }^{13}$ but higher than that found (76 (16)\%) by Brooke et al in preterm infants fed pasteurised human milk. ${ }^{14}$ In the latter study, 
however, faecal excretion of fat was almost twice as high as in our study or in Whyte's study. In the group fed the preterm formula gross energy absorption (93 (SD 2)\%) was slightly higher than that reported (90 (SD 3)\%) by Whyte et al $^{13}$ or by Valman et $a^{15}$ (87 (SD 5)\%) in preterm infants fed formula. Fat absorption was also slightly higher in our infants (88 (SD 5)\%), however, than in Whyte's (85 (SD 5)\%) or Valman's study (83 (SD 5)\%). As in the study of Brooke and Wood, ${ }^{16}$ we found a highly significant positive relation between faecal loss of gross energy and faecal excretion of fat (Fig. 1). The good fat absorption in our infants fed formula is probably due to the use of medium chain triglycerides as part of fat, whereas the poor fat absorption observed in some preterm infants fed banked human milk can be explained by the inactivation of lipase (stimulated by bile salt) by pasteurisation. ${ }^{17}$ We found that protein net absorption was significantly lower in the group fed human milk than in the group fed formula. This might be due to the presence of poorly degraded immunoglobulins in human milk. ${ }^{18}$

We calculated that net absorption of carbohydrate derived energy averaged $92.6 \%$ with human milk and $97 \%$ with formula (Fig. 2). There are few published data concerning carbohydrate absorption in neonates. In term infants aged 2 weeks Southgate and Barrett found a net absorption of carbohydrate that averaged $96.9 \%$ with breast milk and $99.9 \%$ with cow's milk preparation. ${ }^{6}$ In very low birthweight infants fed human milk or formula Atkinson et al found coefficients of lactose absorption of about $99 \%$ during the first weeks of life. ${ }^{8}$ Carbohydrate balance studies are, however, notoriously difficult to interpret. In both studies carbohydrate in

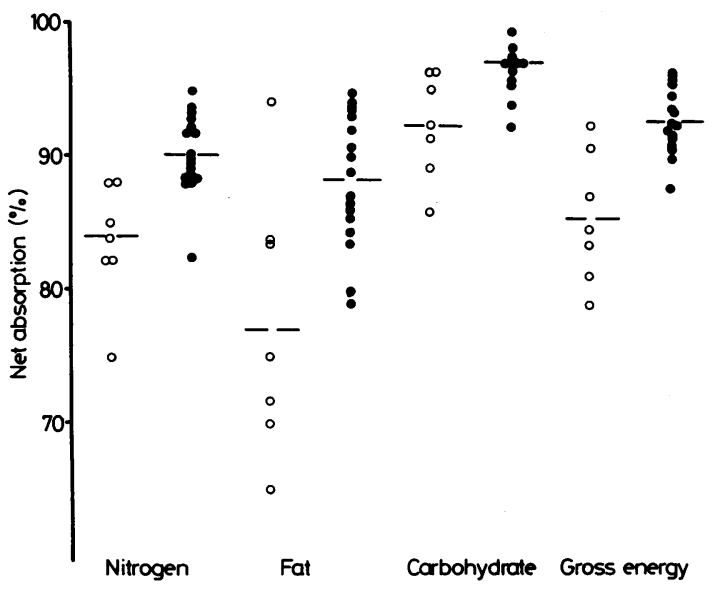

Fig. 2 Coefficients of net absorption of nitrogen, fat, carbohydrate derived energy, and gross energy in preterm infants fed banked human milk $(\mathrm{O})$ or a preterm formula (O).

stools was measured by determination of lactose and reducing substances only. This method does not permit total quantitation of faecal loss of energy derived from carbohydrate because carbohydrate malabsorbed in the small intestine can be converted by colonic flora into short chain organic acids, which are not completely absorbed. ${ }^{19}$ In our study the intake and faecal excretion of carbohydrate was calculated from the total energy content less the sum of energy related to measured nitrogen and fat contents. This technique of assessing net absorption of carbohydrate derived energy has the theoretical advantage of taking into account faecal excretion of carbohydrate as well as by products resulting from

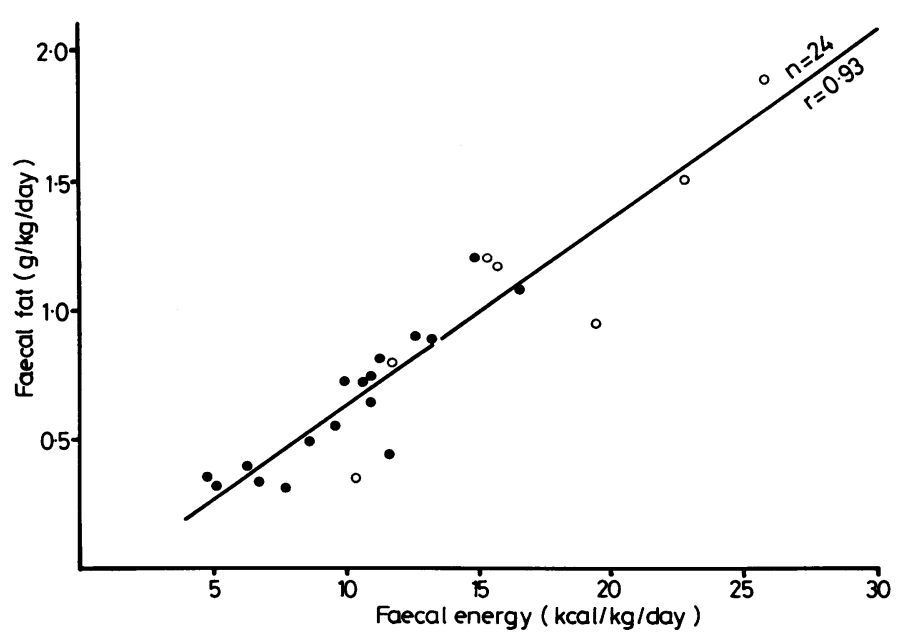

Fig. 1 Relation between faecal fat and faecal energy in three day stool collections from 24 preterm infants fed banked human milk (O) or a preterm formula (O). 
bacterial degradation of malabsorbed carbohydrate. There are, however, some reservations about this method. Despite the use of freezing, short chain organic acids, which are volatile at acid $\mathrm{pH}$, may have been lost in the process of collection or processing. The assumption that stool fat was present only as long chain triglycerides seems acceptable according to the pattern of newborn faecal lipids. ${ }^{20}$ But the assumption that stool nitrogen was present as protein or amino acids only may result in slightly underestimating carbohydrate derived energy as some of the stool nitrogen was presumably also present as urea and ammonia. ${ }^{9}$ The calculation of apparent carbohydrate absorption may also be influenced by the faecal excretion of mucus, which is a potentially non-dietary source of stool carbohydrate. Net absorption of carbohydrate derived energy was lower in the group fed human milk than in the group fed formula. This might result from quantitative and qualitative differences in colonic bacteria. Another explanation might be the presence of numerous poorly absorbed oligosaccharides in human milk $-2.4 \mathrm{~g} / \mathrm{dl}$ in colostrum and $1.2 \mathrm{~g} / \mathrm{dl}$ in mature milk. ${ }^{21}$ The mean coefficient of carbohydrate derived energy absorption in the group fed formula containing $75 \%$ lactose and $25 \%$ glucose polymer was similar to that observed by Kien et al in four premature infants fed a formula containing $50 \%$ lactose and $50 \%$ glucose polymer. ${ }^{9}$

In summary, this study shows that there are differences between net absorption of macronutrients in premature infants fed human milk and preterm formula, resulting in a significantly higher faecal loss of energy with pasteurised human milk. The analysis of production of breath hydrogen by premature infants up to at least 50 days of age has suggested that greater than $66 \%$ of dietary lactose may reach the colon. ${ }^{2}$ Formulas have been developed, therefore, that contain decreased lactose concentration with carbohydrate energy supplemented with glucose polymer. Our study indicates that overall, in terms of energy, net absorption of carbohydrate is quite satisfactory from either source. Our data, however, give an estimation of 'apparent' as opposed to 'true' absorption of carbohydrate. In the absence of data on serum glucose concentrations, breath hydrogen, or excretion of labelled carbon dioxide it is impossible to determine whether absorption occurred in the small bowel through membranous digestion or in the colon by resorption of short chain organic acids produced by the microflora. This salvage pathway may be important in view of raised excretion of breath hydrogen by infants fed lactose or glucose polymer. ${ }^{22}$

Dr M De Curtis was supported by a fellowship from the Nestlé Nutrition Foundation.

\section{References}

1 Auricchio S, Rubino M, Mürset G. Intestinal glycosidase activities in the human embryo, fetus and newborn. Pediatrics 1965;35:944-54.

2 MacLean WC, Fink BB. Lactose malabsorption by premature infants: magnitude and clinical significance. $J$ Pediatr 1980;97:383-8.

${ }^{3}$ Roggero P, Mosca F, Motta G, et al. Sugar absorption in healthy preterm and full-term infants. Journal of Pediatric Gastroenterology and Nutrition 1986;5:214-9.

4 Paige DM, Mellits ED, Chiu FY, Davis L, Bayless TM, Cordano A. Blood glucose rise after lactose tolerance testing in infants. Am J Clin Nutr 1978;31:222-5.

5 MacLean WC Jr, Fink BB, Schoeller DA, Wong W, Klein PD. Lactose assimilation by full-term infants: relation of $\left({ }^{13} \mathrm{C}\right)$ and $\mathrm{H}_{2}$ breath tests with fecal $\left({ }^{13} \mathrm{C}\right)$ excretion. Pediatr Res 1983;17:629-33.

6 Southgate DAT, Barrett IM. The intake and excretion of calorific constituents of milk by babies. Br J Nutr 1966;20: 363-72.

7 Senterre J. Net absorption of starch in low birth weight infants. Acta Paediatr Scand 1980;69:653-7.

8 Atkinson SA, Bryan MH, Anderson GH. Human milk feeding in premature infants: protein, fat, and carbohydrate balance in the first two weeks of life. J Pediatr 1981;99:617-24.

${ }^{9}$ Kien CL, Sumners JE, Stetina JS, Heimler R, Grausz JP. A method for assessing carbohydrate energy absorption and its application to premature infants. Am J Clin Nutr 1982;36:910-6.

10 Senterre J, Sodoyez-Goffaux F, Lambrechts A. Metabolic balance studies in premature babies. I. Methodology. Acta Paediatrica Belgica 1971;25:133-42.

11 Kien CL, Palombo J, Stetina J. Comparative analysis of fecal content of medium and long chain triglycerides using two methods. Clin Chim Acta 1981;113:339-42.

12 De Curtis M, Senterre J, Rigo J. Estimated and measured energy content of infant formulas. Journal of Pediatric Gastroenterology and Nutrition 1986;5. (In press.)

13 Whyte RK, Haslam R, Vlanic C, et al. Energy balance and nitrogen balance in growing low birthweight infants fed human milk or formula. Pediatr Res 1983;17:891-8.

14 Brooke OG, Wood C, Barley J. Energy balance, nitrogen balance, and growth in preterm infants fed expressed breast milk, a premature formula, and two low-solute adapted formulae. Arch Dis Child 1982;57:898-904.

15 Valman HB, Aikens R. David-Reed Z, Garrow JS. Retention of nitrogen, fat, and calories in infants of low birth weight on conventional and high-volume feeds. Br Med J 1974;iii:319-20.

16 Brooke OG, Wood C. Relation between faecal fat and energy in preterm infants. Arch Dis Child 1983;58:305-6.

17 Williamson S, Finucane E, Ellis H, Gamsu HR. Effect of heat treatment of human milk on absorption of nitrogen, fat, sodium, calcium, and phosphorus by preterm infants. Arch Dis Child 1978;53:555-63.

18 Ogra SS, Weintraub D, Ogra PL. Immunologic aspect of human milk. III Fat and absorption of cellular and soluble components in the gastrointestinal tract of the newborn. J Immunol 1977;119:245-8.

19 McNeil NI. The contribution of the large intestine to energy supplies in man. Am J Clin Nutr 1984;30:338-42.

20 Watkins JB, Bliss CM, Donaldson RM, Lester R. Characterization of newborn fecal lipid. Pediatrics 1974;53:511-5.

21 Blanc B. Biochemical aspects of human milk; comparison with bovine milk. World Rev Nutr Diet 1981;36:1-89.

22 Shulman RJ, Wong WW, Irving CS, Nichols BL, Klein PD. Utilization of dietary cereal by young infants. $J$ Pediatr 1983;103:23-8.

Correspondence to Professor J Senterre, Department of Paediatrics, Bavière University Hospital, 4020 Liège, Belgium.

Received 1 June 1986 